\begin{tabular}{ccc}
\hline & Jurnal Inovasi Pembelajaran Fisika \\
(INPAFI) & INPAFI \\
\hline
\end{tabular}

\title{
PENGARUH MODEL PEMBELAJARAN BERBASIS MASALAH TERHADAP HASIL BELAJAR SISWA PADA MATERI POKOK MOMENTUM DAN IMPULS DI KELAS X SEMESTER II SMA NEGERI 3 MEDAN T.P. 2016/2017
}

\author{
Lindang Marturasi Pakpahan dan Rappel Situmorang \\ Jurusan Fisika FMIPA Universitas Negeri Medan \\ lindangpakpahan@gmail.com, situmorangrappel@gmail.com
}

Diterima: September 2018 . Disetujui: Oktober 2018 . Dipublikasikan: Nopember 2018

\begin{abstract}
ABSTRAK
Penelitian ini bertujuan untuk mengetahui hasil belajar siswa pada materi pokok Momentum dan Impuls dengan menggunakan model pembelajaran berbasis masalah di kelas X SMA Negeri 3 Medan. Jenis penelitian ini adalah quasi experiment. Sampel penelitian 2 kelas ditentukan dengan teknik random sampling yaitu kelas X-MIA 1 sebagai kelas eksperimen diberi perlakuan model pembelajaran berbasis masalah dan kelas X-MIA 4 sebagai kelas control diberi perlakuan pembelajaran konvensional. Instrumen penelitian adalah tes hasil belajar berbentuk essay yang terdiri dari 8 soal, lembar observasi penilaian sikap dan keterampilan. Hasil nilai pretes kelas eksperimen diperoleh nilai rata-rata 24,32 dan kelas kontrol diperoleh nilai rata-rata 23,96. Hasil penelitian diperoleh bahwa nilai rata-rata postes kelas eksperimen yaitu 70,04 dan kelas kontrol yaitu 60,88 . Hasil analisis uji t didapat thitung $>$ tabel $(4,341>1,676)$ sehingga ada perbedaan yang signifikan hasil belajar fisika siswa akibat pengaruh model pembelajaran berbasis masalah pada materi Momentum dan Impuls di kelas X SMA Negeri 3 Medan T.P 2016/2017.
\end{abstract}

Kata Kunci : pembelajaran berbasis masalah, hasil belajar, momentum dan impuls

\begin{abstract}
This study aims to determine the student's learning outcomes in the subject matter Momentum and Impulse by using Problem Based Learning model in class X SMA Negeri 3 Medan. The research was quasi experiment. The sample of the two classes was determined by the cluster random sampling technique, that class X MIA- 1 as a experimental class with problem based learning and X MIA-4 as the control class with conventional learning. The research instrument was learning outcomes test of an essay which consist of 8 questions, an attitude and skills assessment observation sheet. The result of pre-test grade experiment was 24,32 and pre-test grade control was 23,96 . The result of the research was that the average of the experimental class pos-test was 70,04 and the average of control class pos-test was 60,88 . The result of $t$ test analysis was thitung $>$ tabel $(4,341>1,676)$, hence there was a significant influence of student's learning outcomes due to the influence of problem based learning model in the material of Momentum and Impulse in class X SMA Negeri 3 Medan TP 2016/2017.
\end{abstract}

Keyword : problem based learning, learning outcomes, momentum and impulse 
Lindang Marturasi Pakpahan dan Rappel Situmorang : Pengaruh Model Pembelajaran Berbasis Masalah Terhadap Hasil Belajar Siswa Pada Materi Pokok Momentum dan Impuls di Kelas X Se me ster II

SMA Negeri 3 Medan T.P. 2016/2017

\section{PENDAHULUAN}

Salah satu pola pembelajaran Kurikulum 2013 adalah siswa aktif mencari pengetahuan. Hal ini sesuai dengan hakikat pembelajaran fisika. Fisika harus dipandang sebagai proses dan produk (Collette dan Chiapetta, 1994). Proses yang dimaksud adalah cara berpikir (a way of thinking) dan cara menyelidiki (a way of investigating). Sejalan dengan hal tersebut, Kurikulum 2013 menghendaki siswa melalui proses ilmiah untuk mempelajari pengetahuan. Siswa diharapkan dapat membangun sendiri pengetahuan yang ada dalam benaknya, mencari dan menemukan sendiri makna segala sesuatu yang dipelajari. Nyatanya pelaksanaan pembelajaran kurikulum 2013 ini masih belum maksimal dikarenakan guru masih menggunakan model pembelajaran yang kurang tepat sehingga berpengaruh pada hasil belajar siswa.

Hasil studi pendahuluan yang dilakukan di SMA Negeri 3 Medan dengan menggunakan instrumen angket yang disebarkan kepada 37 siswa kelas X MIA 1 diperoleh bahwa $86,48 \%$ siswa mengatakan fisika itu sulit dan membosankan, 8,10 \% siswa mengatakan pelajaran fisika biasa saja, dan $5,40 \%$ siswa mengatakan pelajaran fisika itu menarik dan menantang. Dilihat dari kesukaan siswa terhadap fisika maka diperoleh $78,37 \%$ siswa mengatakan tidak menyukai fisika, $16,21 \%$ mengatakan biasa saja, dan 5,40\% mengatakan suka belajar fisika. Hal ini memperlihatkan bahwa minat siswa terhadap belajar fisika sangat rendah dimana $86,48 \%$ siswa menyatakan pelajaran fisika itu sulit dan membosankan dan sebanyak 78,37\% siswa tidak suka belajar fisika.

Wawancara yang dilakukan peneliti kepada salah seorang guru bidang studi fisika di SMA Negeri 3 Medan diketahui bahwa hasil ulangan harian fisika belum memuaskan, dimana nilai rata-rata ulangan harian berkisar antara 55-65. Dilihat dari nilai kriteria ketuntasan minimal (KKM) yang ditetapkan sekolah yaitu 70, maka bisa dikatakan banyak siswa yang belum memenuhi KKM. Hasil wawancara juga menyatakan bahwa dalam proses pembelajaran guru menggunakan metode ceramah. Hal ini membuat siswa kurang aktif ketika belajar fisika karena pembelajaran fisika yang dilakukan masih berpusat kepada guru dan guru kurang memberikan kesempatan kepada siswa untuk berinteraksi dengan teman sekelasnya sehingga pembelajaran menjadi pasif. Peneliti juga menemukan bahwa praktikum jarang dilakukan. Ini membuat siswa menjadi kurang paham dalam mempelajari fisika. Siswa hanya sekedar mengetahui konsep tersebut tanpa mampu membuktikan benar tidaknya konsep yang telah mereka pelajari karena siswa hanya fokus untuk mengerjakan soal.

Berdasarkan uraian masalah diatas, perlu diterapkan suatu model pembelajaran yang sesuai dan mampu meningkatkan hasil belajar fisika siswa. Salah satu model yang cocok diterapkan dalam belajar fisika adalah model pembelajaran berbasis masalah (problem based learning(PBL)). Permasalahan tersebut diharapkan dapat teratasi dengan menerapkan model PBL. Sani (2014:80) berpendapat bahwa pembelajaran berbasis membutuhkan kemampuan untuk bertanya, mengidentifikasi dan menganalisis masalah, mengobservasi, mengumpulkan informasi, mengolah informasi, dan mengembangkan konsep sehingga dapat menyelesaikan masalah yang dikaji. Keseluruhan kemampuan yang dimiliki PBL sangat mendukung kegiatan pembelajaran dengan pendekatan saintifik.

Model PBL ini memiliki kelebihan untuk mendorong siswa agar memiliki kemampuan memecahkan masalah dalam situasi nyata dimana masalah-masalah pada PBL berhubungan dengan kehidupan sehari-hari, dengan model PBL siswa akan lebih aktif, karena dalam model PBL proses belajar mengajar dipusatkan pada siswa. Pelajar diminta untuk saling berkolaborasi menganalisis masalah yang diberikan serta mencari solusi yang terbaik dari masalah tersebut.

Pengaruh model pembelajaran berbasis masalah ini sudah pernah diteliti oleh Kharida dkk (2009) diperoleh hasil belajar kognitif meningkat secara signifikan dari siklus 1 ke 
siklus 2. Besar peningkatan hasil belajar adalah 26\% dengan ketuntasan belajar secara klasikal 86.67\%. Aktivitas belajar siswa dan guru meningkat sebesar 33\%. Hasil yang sama dengan penelitian Rerung dkk (2017) menggunakan model pembelajaran berbasis masalah diperoleh peningkatan hasil belajar kognitif dan psikomotorik. Hal ini dilihat berdasarkan peningkatan persentase KBK pada siklus I sebesar $64 \%$ dan siklus II menjadi $84 \%$. Hasil penelitian oleh Saputri dkk (2015) juga menunjukkan bahwa rata-rata nilai postes yang diperoleh kelas eksperimen adalah 76 dan ratarata nilai postes kelas kontrol adalah 70 .

Berdasarkan uraian latar belakang tersebut maka peneliti akan melakukan penelitian untuk mengetahui hasil belajar fisika siswa yang dapat ditingkatkan dengan menggunakan model pembelajaran berbasis masalah.

\section{METODE PENELITIAN}

Penelitian ini telah dilaksanakan di SMA Negeri 3 Medan yang beralamat di Jalan Budi Kemasyarakatan No. 3 Kecamatan Medan Barat. Pelaksanaan dilakukan pada Semester II T.P. 2016/2017. Populasi penelitian merupakan seluruh siswa kelas $\mathrm{X}$ yang terdiri dari 11 kelas. Sampel penelitian ini terdiri dari 2 kelas yakni kelas X - MIA 1 sebagai kelas eksperimen dan kelas X - MIA 4 sebagai kelas kontrol.

Jenis penelitian ini termasuk jenis kuasi eksperimen dengan desain penelitian menggunakan model two group pretestposttest design yang digambarkan pada tabel 1.

Tabel 1. Two Group Pretest - Posttest Design

\begin{tabular}{|l|c|c|c|}
\hline Kelompok & Pretes & Perlakuan & Postes \\
\hline $\begin{array}{l}\text { Kelas } \\
\text { eksperimen }\end{array}$ & $\mathrm{T}_{1}$ & $\mathrm{X}$ & $\mathrm{T}_{2}$ \\
\hline $\begin{array}{l}\text { Kelas } \\
\text { Kontrol }\end{array}$ & $\mathrm{T}_{1}$ & $\mathrm{Y}$ & $\mathrm{T}_{2}$ \\
\hline
\end{tabular}

Keterangan :

$\mathrm{T}_{1}=$ Pretes diberikan kepada kelas eksperimen dan kelas kontrol sebelum perlakuan

$\mathrm{T}_{2}=$ Postes diberikan setelah perlakuan pada kelas eksperimen dan kelas kontrol

$\mathrm{X}=$ Pengajaran dengan menerapkan model Pembelajaran Berbasis Masalah
$\mathrm{Y}=$ Pengajaran dengan menerapkan pembelajaran konvensional

Peneliti memberikan pretes pada kelas eksperimen dan kelas kontrol. Instrumen yang digunakan pada penelitian ini adalah tes hasil belajar berbentuk essay terdiri dari 8 soal. Tes hasil belajar terlebih dahulu divaliditas oleh dua orang dosen. Setelah data pretes diperoleh, dilakukan analisis data dengan uji normalitas yaitu uji lilliefors, uji homogenitas dan uji kesamaan varians. Setelah itu dilakukan pengujian hipotesis uji $\mathrm{t}$ dua pihak untuk mengetahui kemampuan awal siswa pada kedua kelompok sampel. Selanjutnya peneliti mengajarkan materi pelajaran dengan menggunakan model pembelajaran berbasis masalah pada kelas eksperimen dan pembelajaran konvensional pada kelas kontrol. Kemudian diberikan postes kepada kelas kontrol dan kelas eksperimen dan melakukan uji hipotesis hasil belajar dengan menggunakan statistika $\mathrm{t}$ untuk melihat perbedaan hasil belajar akibat pengaruh model pembelajaran berbasis masalah.

\section{HASIL DAN PEMBAHASAN}

\section{a. Hasil Penelitian}

Data yang dikumpulkan dalam penelitian ini meliputi data hasil belajar pada materi Momentum dan Impuls. Sampel penelitian ini melibatkan dua kelas yang diberikan perlakuan pembelajaran berbeda yaitu, 1) kelas eksperimen dengan model pembelajaran berbasis masalah, 2) kelas kontrol dengan pembelajaran konvensional. Hasil data pretes siswa kelas eksperimen dan kelas kontrol dapat ditunjukkan pada Gambar 1 dan Gambar 2.

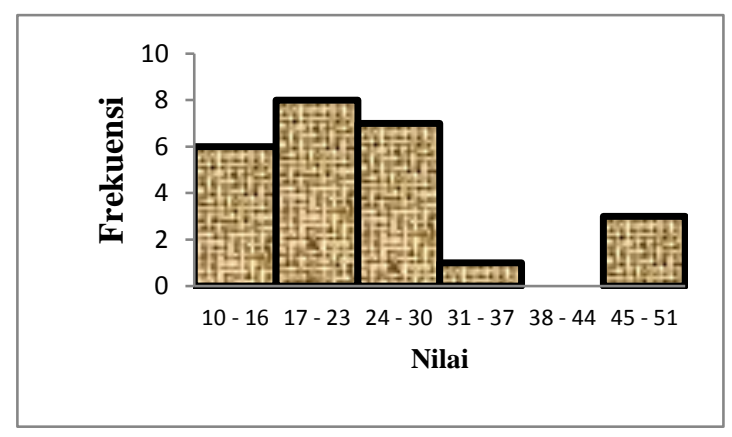

Gambar 1. Diagram batang nilai pretes kelas eksperimen 
Lindang Marturasi Pakpahan dan Rappel Situmorang : Pengaruh Model Pembelajaran Berbasis Masalah Terhadap Hasil Belajar Siswa Pada Materi Pokok Momentum dan Impuls di Kelas X Se me st er II

SMA Negeri 3 Medan T.P. 2016/2017

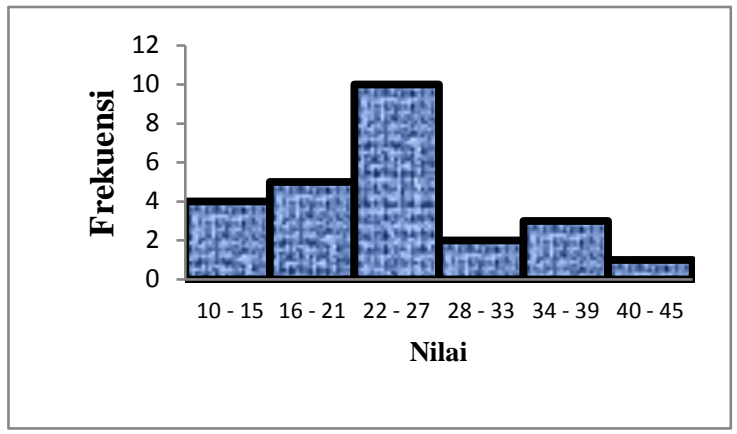

Gambar 2. Diagram batang nilai pretes kelas eksperimen

Berdasarkan Gambar 1 dan 2 nilai pretes yang diperoleh siswa pada kedua kelas tidak jauh berbeda. Hasil pretes kelas eksperimen yaitu 24,32 dengan standar deviasi 10,53 dan hasil pretes kelas kontrol yaitu 23,96 dan standar deviasi 8,42. Hal ini berarti bahwa kemampuan awal kedua kelas sama dan perolehan nilai yang merata.

Distribusi frekuensi data postes siswa kelas eksperimen dan kontrol dapat divisualisasikan pada Gambar 3.

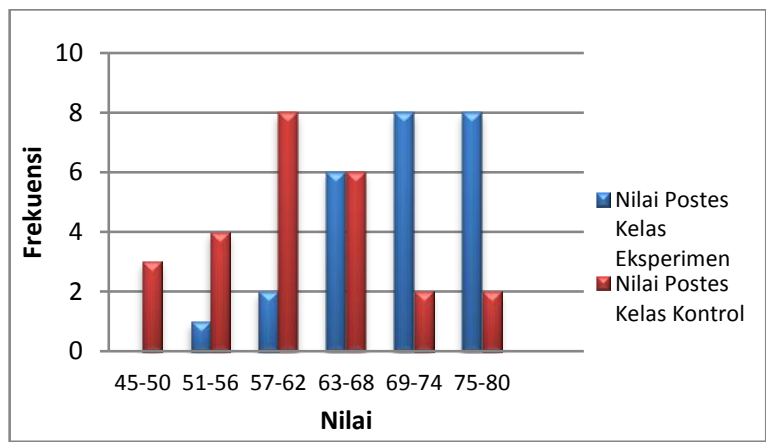

Gambar 3. Nilai Postes Kelas Eksperimen dan Kontrol

Gambar 3 menunjukkan bahwa nilai postes kelas eksperimen lebih tinggi dari nilai postes kelas kontrol, perbandingan rata-rata nilainya adalah 70,04 dengan standar deviasi 6,61 dan 60,88 dengan standar deviasi 8,24. Gambar 3 juga menunjukkan bahwa jumlah siswa yang memperoleh nilai tinggi di kelas eksperimen lebih banyak dibandingkan kelas kontrol dimana siswa yang mencapai Kriteria Ketuntasan Minimum (KKM) di kelas eksperimen 64\% atau 16 siswa dan dikelas kontrol $16 \%$ atau 4 siswa. Perbedaan distribusi nilai hasil belajar antara kedua kelas ini menunjukkan kelas eksperimen lebih baik dibandingkan kelas kontrol.

Selain hasil belajar, dalam penelitian ini juga dilakukan observasi yaitu observasi penilaian sikap dan keterampilan yang dilakukan selama proses pembelajaran. Observasi penilaian sikap ini dilakukan di kelas eksperimen dan kontrol. Penilaian keterampilan hanya dilakukan di kelas eksperimen. Hal ini tidak diberlakukan di kelas kontrol karena metode pada pembelajaran konvensional tidak menerapkan metode eksperimen.

Hasil perkembangan sikap (afektif) siswa setiap pertemuan ditunjukkan pada tabel 2.

Tabel 2. Penilaian sikap siswa kelas eksperimen dan kontrol.

\begin{tabular}{|c|c|c|c|c|c|}
\hline \multirow[b]{2}{*}{ No } & \multirow{2}{*}{$\begin{array}{c}\text { Perte } \\
\text { muan } \\
\text { Ke- }\end{array}$} & \multicolumn{2}{|c|}{$\begin{array}{c}\text { Kelas } \\
\text { eksperimen }\end{array}$} & \multicolumn{2}{|c|}{ Kelas Kontrol } \\
\hline & & $\begin{array}{l}\text { Rata- } \\
\text { rata } \\
\text { Sikap }\end{array}$ & $\begin{array}{c}\text { Kriter } \\
\text { ia }\end{array}$ & $\begin{array}{c}\text { Rata- } \\
\text { rata } \\
\text { Sikap }\end{array}$ & $\begin{array}{c}\text { Krite } \\
\text { ria }\end{array}$ \\
\hline 1 & I & 68,8 & Baik & 6 & Baik \\
\hline 2 & II & 76 & Baik & 60 & 3aik \\
\hline 3 & III & 81,4 & $\begin{array}{l}\text { Sanga } \\
\text { t Baik }\end{array}$ & 71,8 & Baik \\
\hline \multicolumn{2}{|r|}{ rata } & 75,4 & Baik & 67,87 & Baik \\
\hline
\end{tabular}

Tabel 2 menunjukkan bahwa nilai ratarata skala sikap siswa di kelas eksperimen dan di kelas kontrol terdapat peningkatan setiap pertemuan, dimana pada kelas eskperimen hasil yang diperoleh yaitu pertemuan I $(68,8)$ kategori cukup baik, pertemuan II (76) kategori baik, pertemuan III $(81,4)$ mencapai nilai tertinggi sangat baik. Nilai rata-rata sikap siswa kelas kontrol yaitu pada pertemuan I $(62,8)$ kategori cukup baik, pertemuan II (69) kategori cukup baik, pertemuan III $(71,8)$ mencapai nilai tertinggi kategori baik tetapi skor rata-rata secara keseluruhan di kelas eksperimen lebih merata dan perkembangan sikap mulai pertemuan 1-3 lebih signifikan. Hal ini mengindikasikan bahwa sikap siswa di kelas eksperimen lebih baik daripada kelas kontrol. 
Walaupun hasil rata-rata nilai kedua kelas sampel berada pada kategori baik (B).

Perkembangan keterampilan siswa di kelas eksperimen dapat dilihat dari tabel 3.

Tabel 3. Perkembangan Keterampilan Siswa Kelas Eksperimen

\begin{tabular}{|c|l|c|c|}
\hline No & Pertemuan & Rata-rata & Kriteria \\
\hline 1 & Pertemuan I & 65,33 & Baik \\
\hline 2 & Pertemuan II & 74,67 & Baik \\
\hline 3 & Pertemuan III & 83,99 & Sangat Baik \\
\hline & Rata-rata & $\mathbf{7 4 , 6 7}$ & Baik \\
\hline
\end{tabular}

Tabel 3 menunjukkan bahwa keterampilan siswa di kelas eksperimen mengalami peningkatan selama pembelajaran dengan PBL. Nilai rata-rata pertemuan I adalah $65,33 \%$ kategori kurang, pertemuan II 74,67 \% kategori cukup terampil, dan pertemuan III $84,33 \%$ dengan kategori baik (terampil). Secara keseluruhan keterampilan siswa dikelas eksperimen kategori baik.

\section{b. Pembahasan}

Hasil penelitian menunjukkan bahwa ada pengaruh model pembelajaran berbasis masalah terhadap hasil belajar siswa pada materi pokok Momentum dan Impuls di Kelas X Semester II SMA Negeri 3 Medan T.P 2016/2017. Hal ini diperkuat dengan adanya perbedaan hasil belajar antara kelas eksperimen dengan kelas kontrol. Perolehan nilai rata-rata pretes siswa di kelas kontrol sebesar 23,96 dan nilai rata-rata postes sebesar 60,88 sedangkan di kelas eksperimen diperoleh nilai rata-rata pretes siswa sebesar 24,32 dan nilai rata-rata postes sebesar 70,04. Ini membuktikan kemampuan siswa yang menggunakan model pembelajaran pembelajaran berbasis masalah lebih baik daripada model pembelajaran konvensional. Hasil tersebut diperoleh karena model pembelajaran berbasis masalah merupakan suatu model yang didasarkan pada banyaknya permasalahan yang membutuhkan penyelidikan autentik yakni penyelidikan yang membutuhkan penyelesaian nyata dari permasalahan yang nyata. Pembelajaran berbasis masalah merupakan inovasi dalam pembelajaran karena dalam PBM kemampuan berpikir siswa betul-betul dioptimalisasikan melalui proses kerja kelompok atau tim yang sistematis, sehingga siswa dapat memberdayakan, mengasah, menguji, dan mengembangkan kemampuan berpikirnya secara berkesinambungan. (Rusman, 2012:229)

Peneliti mengawali penelitian dengan memberikan pretes kepada siswa untuk melihat kemampuan setiap siswa di kedua kelas. Setelah memberikan pretes, kedua kelas tersebut diberi perlakuan yang berbeda. Kelas ekperimen diberi perlakuan menggunakan model pembelajaran berbasis masalah sedangkan kelas kontrol diberi perlakuan dengan menggunakan pembelajaran konvensional. Pada kelas eksperimen saat selesai melaksanakan pretes, peneliti membagi siswa kedalam 6 kelompok yang setiap kelompoknya terdiri dari 6 - 7 siswa. Pembagian kelompok ini dilakukan secara acak oleh peneliti.

Kelas eksperimen diberi perlakuan menggunakan model pembelajaran berbasis masalah terdapat perbedaan hasil belajar siswa dibanding dengan pembelajaran konvensional. Hal ini dikarenakan menurut Arends (2008:57) pembelajaran berbasis masalah terdiri dari lima langkah utama yang dimulai dengan guru memperkenalkan siswa dengan situasi masalah dan diakhiri dengan penyajian dan dianalisis hasil kerja siswa yang membuat pengetahuan siswa menjadi lebih baik dan meningkat. Fase pertama yaitu memberikan orientasi tentang permasalahannya kepada siswa, pada pertemuan pertama siswa masih bingung untuk memberikan hipotesis dari masalah yang diberikan peneliti, siswa masih banyak yang diam, setelah di beri pengarahan pada pertemuan kedua siswa mulai memberikan hipotesis, pada pertemuan ketiga banyak siswa yang memberikan hipotesis dari masalahmasalah yang diberikan peneliti. Fase kedua dan ketiga yaitu mengorganisasikan siswa untuk meneliti dan membantu investigasi mandiri dan kelompok siswa, pada pertemuan pertama terjadi keributan yaitu saat praktikum berlangsung siswa masih banyak yang bingung dalam pelaksanaan praktikum, belum ada kerjasama siswa dalam berkelompok, ributnya siswa disebababkan karena mereka tidak mengetahui nama-nama alat prkatikum yang akan mereka pakai dan juga bingung karena mereka juga tidak mengetahui apa fungsi alat 
Lindang Marturasi Pakpahan dan Rappel Situmorang : Pengaruh Model Pembelajaran Berbasis Masalah Terhadap Hasil Belajar Siswa Pada Materi Pokok Momentum dan Impuls di Kelas X Se me st e r II

SMA Negeri 3 Medan T.P. 2016/2017

praktikum tersebut. Mereka juga kurang kerja sama dalam kelompok karena mereka bingung dengan pembelajaran yang diberikan peneliti dimana selama ini pembelajaran yang diterapkan hanya teori saja tidak pernah melakukan praktikum langsung tetapi setelah dilihat dari pertemuan kedua saat praktikum siswa sudah mulai terbiasa dalam melaksanakan praktikum dan pada pertemuan ketiga kegiatan praktikum berjalan dengan baik, siswa tidak lagi bingung serta dapat menemukan solusi dari permasalahan yang telah diberikan peneliti. Fase keempat dan kelima yaitu mengembangkan dan mempresentasikan hasil karya, menganalisis dan mengevaluasi proses mengatasi masalah, pada pertemuan pertama siswa belum bisa untuk menghubungkan masalah dengan konsep sehingga membuat kesimpulan kurang sesuai dengan masalah yang diberikan, sehingga peneliti kembali menjelaskan kepada siswa agar kesimpulan harus sesuai dengan masalah. Pertemuan kedua dan ketiga siswa semakin paham dan kesimpulan yang didapat hampir sesuai dengan tujuan.

Penggunaan model pembelajaran berbasis masalah pada saat proses pembelajaran tentunya mempunyai dampak atau pengaruh yang baik terhadap kemampuan siswa, karena disetiap tahap atau fase dari model pembelajaran berbasis masalah dapat membina dan mengembangkan keterampilan mengamati, mengumpulkan dan mengolah data, merumuskan penjelasan, membuat dan menguji hipotesis, merancang percobaan dan menggambarkan kesimpulan. Pembelajaran konvensional jarang sekali tergambar keterampilan-keterampilan tersebut, karena dalam pembelajaran konvensional biasanya hanya menggunakan metode ceramah dan penugasan mengerjakan soal-soal. Menurut Sanjaya (2006:147) metode ceramah yaitu cara menyajikan pelajaran melalui penuturan secara langsung kepada sekelompok siswa. Metode ceramah sudah terbiasa dilakukan, sifatnya berpusat pada guru, sehinggga pelaksanaanya kurang memperhatikan keseluruhan situasi belajar.

Pembelajaran fisika juga tidak hanya menuntut siswa untuk mengerti rumus-rumus tapi juga harus dibina dalam pembelajaran yang nyata agar siswa lebih dapat memahami dan mengerti. Tugas guru adalah membantu para siswa merumuskan tugas-tugas, dan bukan menyajikan tugas-tugas pelajaran dan objek pelajaran tidak dipelajari dari buku, tetapi dari masalah yang ada disekitarnya (Trianto, 2009:96). Pembentukan kelompok pada model pembelajaran berbasis masalah ini membuat terjadinya interaksi antara siswa dengan siswa dan siswa dengan guru, siswa dapat menukar ide satu sama lain, siswa terlatih untuk berpikir kritis dan terampil untuk memecahkan masalah dalam bidang studi fisika.

Hasil penelitian ini sesuai dengan penelitian terdahulu yaitu oleh Kharida dkk (2009) diperoleh hasil belajar kognitif meningkat secara signifikan dari siklus 1 ke siklus 2. Besar peningkatan hasil belajar adalah 26\% dengan ketuntasan belajar secara klasikal 86.67\%. Aktivitas belajar siswa dan guru meningkat sebesar 33\%. Hal ini terjadi karena di kelas eksperimen menggunakan model pembelajaran berbasis masalah dimana siswa diajak untuk menemukan konsep dari masalahmasalah dalam kehidupan sehari - hari melalui kegiatan eksperimen sehingga dengan begitu aktivitas siswa lebih aktif dan keterampilan mereka dalam kegiatan praktikum menjadi lebih baik. Model pembelajaran berbasis masalah sangat membantu siswa dalam menerima dan memahami pelajaran fisika karena menurut Arends (Trianto, 2007:68) model pembelajaran berbasis masalah adalah suatu pendekatan pembelajaran dimana siswa mengerjakan permasalahan yang autentik dengan maksud untuk menyusun pengetahuan mereka sendiri, mengembangkan inkuiri dan keterampilan berpikir tingkat tinggi, mengembangkan kemandirian dan percaya diri.

Kendala saat menerapkan model pembelajaran berbasis masalah dalam penelitian ini menyebabkan pencapaian hasil belajar kurang maksimal. Kendala-kendala tersebut, seperti: 1) perencanaan kegiatan belajar mengajar dalam RPP tidak sesuai dengan kenyataan karena kurangnya waktu. Hal ini terlihat pada fase keempat saat pelaksanaan mempresentasikan hasil diskusi yang hanya bisa 
menampilkan dua kelompok yang seharusnya 6 kelompok. 2) Kurang kondusifnya pembelajaran disebabkan karena model pembelajaran ini masih baru pertama kali diperkenalkan kepada siswa, sehingga siswa agak canggung dalam pembelajaran, belum terbiasa untuk bekerja kondusif dalam kelompok dan akhirnya juga menyebabkan keributan.3) Siswa kurang dekat dan belum terbiasa dengan alat praktikum, membuat siswa bingung dan canggung dalam melakukan eksperimen. 4) Siswa kurang percaya diri dengan kemampuan yang dimilikinya sehingga siswa cenderung bertanya kepada peneliti. Hal ini disebabkan karena siswa sudah terbiasa dengan metode ceramah dimana guru merupakan sumber utama dari pengetahuan yang didapat siswa.

\section{KESEIMPULAN DAN SARAN}

Berdasarkan hasil analisis dan uji statistik serta pembahasan maka disimpulkan ada perbedaan yang signifikan hasil belajar fisika siswa akibat pengaruh model pembelajaran berbasis masalah pada materi Momentum dan Impuls di kelas X SMA Negeri 3 Medan T.P 2016/2017.

Berdasarkan hasil penelitian dan kesimpulan, maka sebagai tindak lanjut dari penelitian ini disarankan beberapa hal sebagai berikut :

1. Peneliti selanjutnya hendaknya melakukan simulasi sebelum menggunakan model pembelajaran berbasis masalah terhadap siswa, agar siswa lebih memahami dan terlatih dengan cara kerja model pembelajaran berbasis masalah ketika melakukan penelitian, sehingga pembelajaran dengan model pembelajaran berbasis masalah dapat diselesaikan tepat waktu.

2. Saat proses pembelajaran berlangsung sebaiknya menambahkan beberapa pengamat untuk membantu agar pembelajaran siswa lebih terarah dan para pengamat mampu mengamati siswa serta menilai siswa dalam mengumpulkan data untuk lembar penilaian sikap dan keterampilan.

3. Model ini akan lebih baik apabila semua anggota kelompok terlibat aktif selama proses belajar melalui kerja kelompok, maka perlu perorganisasian kelompok yang lebih baik, yaitu jumlah siswa dalam kelompok sebaiknya 3-4 orang saja. Hal ini bertujuan agar setiap anggota dalam tiaptiap kelompok akan lebih mudah diorganisir dan menyelesaikan diskusi kelompok sehingga siswa akan aktif dalam melakukan kegiatan berkelompok.

\section{DAFTAR PUSTAKA}

Arends., (2008), Learning to teach, Edisi ketujuh, Pustaka Belajar, Yogyakarta.

Colette, A.T \& Chiapetta, E.L., (1994), Science Instruction in the Middle and Secondary School (3rd ed), Merril, Newyork.

Kharida, L.A., Rusilowati, K., Pratinyo, K., (2009), Penerapan Model Pembelajaran Berbasis Masalah untuk Peningkatan Hasil Belajar Siswa pada Pokok Bahas Elastisitas Bahan, Jurnal Pendidikan Fisika Indonesia: 5, 83-89.

Rerung, N., Sinon Iriwi L. S., Widyaningsih S.W., (2017), Penerapan Model Pembelajaran Problem Based Learning (PBL) untuk Meningkatkan Hasil Belajar Peserta Didik SMA pada Materi Usaha dan Energi, Jurnal

Ilmiah Pendidikan Fisika Al biruni: 6, (1), 47-55.

Rusman., (2012), Model-ModelPembelajaran, Raja Grafindo Persada. Jakarta.

Sani, R.A., (2014), Pembelajaran Saintifik untuk Implementasi Kurikulum 2013, Bumi Aksara, Jakarta.

Sanjaya, W., (2006), Strategi Pembelajaran Berorientasi Standar Proses Pendidikan, Kencana Prenada MediaGroup, Jakarta.

Saputri, K., Muslim M dan Murniati, (2013), Pengaruh Model Problem Based Learning Terhadap Keterampilan Menyimpulkan Hasil Percobaan Siswa PadaPembelajaran Fisika Di Kelas X SMA Negeri 1 Tanjung Lubuk 
Lindang Marturasi Pakpahan dan Rappel Situmorang : Pengaruh Model Pembelajaran Berbasis Masalah Terhadap Hasil Belajar Siswa Pada Materi Pokok Momentum dan Impuls di Kelas X Se me ster II

SMA Negeri 3 Medan T.P. 2016/2017

Jurnal Inovasi dan $\quad$ Pembelajaran Fisika: 1-

7.

Trianto., (2007), Model-model Pembelajaran

Inovatif Berorientasi Konstrutivistik,

Prestasi Pustaka, Jakarta.

Trianto., (2009), Mendesain Model

Pembelajaran Inovatif-Progresif,

Kencana, Jakarta. 